\title{
Review Article \\ The Recent Understanding of the Neurotrophin's Role in Skeletal Muscle Adaptation
}

\author{
Kunihiro Sakuma ${ }^{1}$ and Akihiko Yamaguchi ${ }^{2}$ \\ ${ }^{1}$ Research Center for Physical Fitness, Sports and Health, Toyohashi University of Technology, 1-1 Hibarigaoka, Tenpaku-cho, \\ Toyohashi 441-8580, Japan \\ ${ }^{2}$ School of Dentistry, Health Sciences University of Hokkaido, Kanazawa, Ishikari-Tobetsu, Hokkaido 061-0293, Japan
}

Correspondence should be addressed to Kunihiro Sakuma, ksakuma@las.tut.ac.jp

Received 27 May 2011; Accepted 24 July 2011

Academic Editor: Aikaterini Kontrogianni-Konstantopoulos

Copyright (C) 2011 K. Sakuma and A. Yamaguchi. This is an open access article distributed under the Creative Commons Attribution License, which permits unrestricted use, distribution, and reproduction in any medium, provided the original work is properly cited.

\begin{abstract}
This paper summarizes the various effects of neurotrophins in skeletal muscle and how these proteins act as potential regulators of the maintenance, function, and regeneration of skeletal muscle fibers. Increasing evidence suggests that this family of neurotrophic factors influence not only the survival and function of innervating motoneurons but also the development and differentiation of myoblasts and muscle fibers. Muscle contractions (e.g., exercise) produce BDNF mRNA and protein in skeletal muscle, and the BDNF seems to play a role in enhancing glucose metabolism and may act for myokine to improve various brain disorders (e.g., Alzheimer's disease and major depression). In adults with neuromuscular disorders, variations in neurotrophin expression are found, and the role of neurotrophins under such conditions is beginning to be elucidated. This paper provides a basis for a better understanding of the role of these factors under such pathological conditions and for treatment of human neuromuscular disease.
\end{abstract}

\section{Introduction}

Neurotrophins are best known for their roles in regulating neuronal survival, plasticity, growth, and death $[1,2]$. As such, they have been studied predominantly in the context of nervous system development and function. However, accumulating evidence suggests that neurotrophins play a more widespread role than originally thought. Accordingly, they are now the focus of study in numerous cell populations across multiple tissue systems. Of these populations, skeletal muscle is of particular interest, because it acts as an abundant source of neurotrophic support throughout development $[3,4]$. In addition, skeletal muscle expresses several neurotrophin receptors, providing the basis for neurotrophin signaling within the muscle compartment [5]. Indeed, neurotrophin knockout mice often exhibit distinct defects in muscle development and function, and to date neurotrophin- (NT-) 4/5 has been implicated in muscle fiber transformation, NT-3 in muscle spindle formation, and nerve growth factor (NGF) in dystrophic muscle pathology [6-8]. Expression profiling has shown that brain-derived neurotrophic factor (BDNF) is differentially expressed in skeletal muscle under various physiological and pathological conditions [4]. Several studies have demonstrated that physical exercise can increase circulating BDNF levels in both healthy humans $[9,10]$ and patients with multiple sclerosis [11]. More recently, Matthews et al. [12] clearly showed the production of BDNF mRNA and protein by human skeletal muscle after 2 hours of ergometer bicycle exercise. In addition, denervation causes alterations of muscle neurotrophin levels $[3,13,14]$, and, in several animal studies, reduced NGF and NT-3 mRNA as well as NGF protein levels have been observed in diabetic muscle [15-18], whereas an increase in BDNF mRNA levels has been reported $[15,19]$.

Glial-cell-line-derived neurotrophic factor (GDNF) was first discovered in glial cells and supports dopaminergic neurons of the central nervous system [20]. GDNF induces sprouting and muscle fiber reinnervation [21] and may be involved in the maintenance of cell body size and the cholinergic phenotype of motoneurons [22]. Earlier studies showed the marked expression of GDNF at neuromuscular junction $(\mathrm{NMJ})$ during early myogenesis and then negligible 
levels. However, several researchers observed clear expression in normal muscles of mice, after denervation, and merosindeficient muscular dystrophy in adult animals.

This paper focuses on the effects of neurotrophins (NGF, BDNF, NT-4/5, and GDNF) on skeletal muscle and how they act as potential regulators of the development, maintenance, function, and regeneration of skeletal muscle fibers. In mice carrying null mutations in the NT-3 or tropomyosin-related kinase (Trk)C gene, numbers of proprioceptive neurons and muscle spindles are dramatically decreased $[8,23]$. Conversely, the embryonic overexpression of NT-3 in developing limb or muscle increases the number of proprioceptive neurons $[24,25]$. However, the muscle morphology in these models is poorly described. In this paper, we did not describe a possible role of NT-3 and the receptor (TrkC) in muscle fiber; only a few studies found some role of NT-3 to muscle morphology [26, 27].

\section{Normal Distribution of Neurotrophins and Their Receptors in Adult Skeletal Muscle}

2.1. Neurotrophins. The level of BDNF expression in animals fuels debate as well. Low levels were reported in developing and postnatal avian and rodent skeletal muscle [3, 2832]. However, other studies including our own could not detect any BDNF expression in developing muscle of mice and rats $[14,33]$. Indeed, neither Western blotting nor immunohistochemistry revealed immunoreactivity in the soleus and several fast-type muscles in Wistar rats at 2-12 weeks of age. To investigate this issue in more detail, recent studies have applied intensified in situ hybridization (ISH) techniques for electron microscopy to detect BDNF mRNA in muscle and, in particular, to determine the cell types (muscle fibers, satellite cells, Schwann cells, fibroblasts, and endothelial cells) that synthesize BDNF. These studies suggest the expression of BDNF to be confined to myofibers in adult rat muscle [34] and that other cells in normal muscle do not contribute to BDNF expression. However, Mousavi and Jasmin [35] demonstrated more recently the expression of BDNF in normal satellite cells of several muscles in adult mice. Using three different methods (reverse transcriptionPCR, in situ hybridization, and immunofluorescence), they found the clear colocalization of both BDNF and the receptor $\mathrm{p} 75^{\mathrm{NTR}}$ with Pax3, a marker of satellite cells, in the diaphragm, soleus, and EDL muscle of mature mice. Furthermore, they showed that BDNF was not expressed at significant levels within mature myofibers and did not accumulate within subsynaptic regions of neuromuscular junctions. Consistent with these observations, Liem et al. [34] reported that subsynaptic regions of NMJs in soleus muscle were devoid of BDNF transcripts. The expression of BDNF in NMJs has been controversial. It has been hypothesized that skeletal-muscle-derived BDNF enhances the survival of innervating motor neurons throughout their lifespan and potentiates neuromuscular transmission $[36,37]$. This hypothesis is supported by several lines of evidence including, for example, the expression of BDNF in skeletal muscle and retrograde transport of exogenously applied BDNF to distinct motor neuron cell bodies [3, 38,
39]. As postulated by Mousavi and Jasmin [35], mature NMJs unlike the central nervous system (CNS) may be stable arrangements that do not require BDNF signaling for remodeling and modulation of neuromuscular transmission.

NT-4/5 expression is dependent on the activity of neuromuscular synapses. Electrical stimulation of motor nerves enhanced NT-4/5 expression in skeletal muscle, and a blockade of neuromuscular endplates with bungarotoxin led to reduced NT-4/5 expression [39]. Although NT-4/5 expression appears relatively strong in skeletal muscle of adult rats, several studies including our own suggest the expression of NT-4/5 to be dependent on fiber type [14, 40]. One study found NT-4/5 to be equally distributed in both muscle types in humans [40], while another, using in situ hybridization and immunohistochemistry, found NT-4/5 to be selectively expressed in the slow-twitch fibers of mice. In contrast, our Western blot analysis [14] demonstrated that NT-4/5 expression is higher in fast-type (extensor digitorum longus, tibialis anterior, and gastrocnemius) than slow-type (soleus) muscles. Immunohistochemical analysis revealed NT-4/5 protein within vesicle-like structures that are diffusely distributed in the cytosol of muscle fibers in the tibialis anterior muscle. Low levels of NT-4/5 immunoreactivity were also observed around the edge of soleus muscle fibers. Furthermore, Carrasco and English [7] found, using Fisher 344 rats, that intramuscular injections of recombinant NT-4/5 $(1.5 \mu \mathrm{g})$ into the soleus muscle of neonates significantly accelerated the normal fast-toslow myosin heavy chain (MHC) isoform transformation. The sequestration of endogeneous NT- $4 / 5$ with TrkB-IgG prevented this transformation from occurring. Intriguingly, administration of another $\operatorname{TrkB}$ ligand did not affect the normal course of the transformation in this muscle. In their study, the developmental upregulation of NT- $4 / 5$ mRNA expression in rat soleus muscle fibers occurred earlier than the upregulation of MHCI mRNA expression associated with muscle fiber transformation. This finding would indicate that the NT- $4 / 5$ protein is expressed more abundantly in the soleus muscle because of the slow-type characteristics. Although the expression pattern of NT-4/5 appears to differ depending on the species of animal and with postnatal growth, NT-4/5 is important for maintaining various functions (fiber-type conversion, survival of motoneuron, the formation of NMJ, etc.) in skeletal muscle.

The expression of GDNF has been found in a variety of tissues and cells outside of the CNS, including skeletal muscle and Schwann cells [21, 41, 42]. Earlier studies indicated that GDNF is important to the survival of motoneurons during myogenesis and regulates the postnatal change from multi-innervation to single innervation. In general, GDNF expression seems to peak during early myogenesis and to be negligible in mature skeletal muscle. A more recent study clearly demonstrated the existence of GDNF mRNA and protein in both slow-type soleus and fast-type EDL muscles, especially the former [43].

2.2. Neurotrophin Receptors. Figure 1 indicates possible interactions between several neurotrophins and these receptors in mammalian muscle. The low-affinity NT receptor 


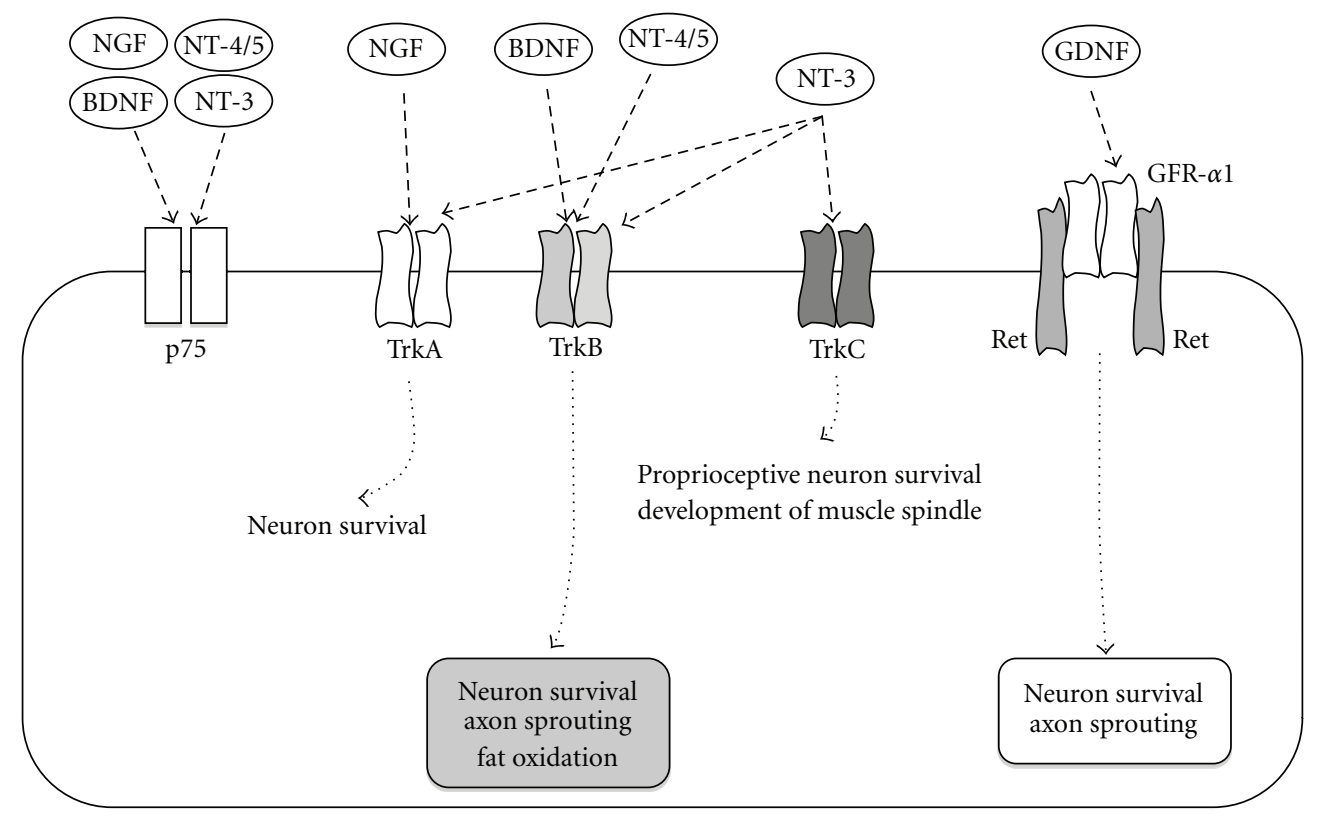

FIGURE 1: The interaction (preference of binding) between neurotrophins and these receptors. The low-affinity receptor p75 ${ }^{\mathrm{NTR}}$ binds all neurotrophins with similar affinity but not different kinetics. Trk receptors are a family of transmembrane glycoprotein, which includes three members, TrkA, TrkB, and TrkC. The full-length TrkA, TrkB, and TrkC have estimated molecular weights of 140, 145, and 145 kDa, respectively. Each Trk preferentially binds a single neurotrophin. TrkA is the receptor for NGF, both BDNF and NT-4/5 bind to TrkB, and NT-3 is the ligand for TrkC. GDNF dimer forms a complex with GFR- $\alpha 1$, and this complex induces dimerization of Ret. BDNF: brain-derived neurotrophic factor, GDNF: glial cell-line derived neurotrophic factor, and NT-4/5: neurotrophin-4/5.

$\left(\mathrm{p} 75^{\mathrm{NTR}}\right)$ binds both neurotrophin precursor proteins and all mature neurotrophins. It is expressed in developing rat myoblasts and in adult rat and chicken muscle [44-46]. In chicks, all somitic cells strongly express $\mathrm{p} 75^{\mathrm{NTR}}$ mRNA during early development [47]. Subsequently, as the somite becomes subdivided into the dermatome, myotome, and sclerotome, p75 ${ }^{\mathrm{NTR}}$ mRNA expression becomes high in dermatome and sclerotome and decreases to low levels in the myotome [45].

In the adult rat, both the long form of TrkA mRNA and a short isoform that lacks 18 base pairs coding for an insert in the extracellular region are expressed in skeletal muscle [45]. TrkB is also found in the muscle of adult mice [48]. Our group found that the truncated $\operatorname{TrkB}$ was highly expressed in muscle, but the full-length $\operatorname{TrkB}$ was also detectable, at least at low levels $[14,45]$. TrkB expression varies depending on the type of skeletal muscle [14, 45]. $\operatorname{TrkB}$ is more abundant around the edge of myofibers of the soleus muscle than gastrocnemius muscle. Full-length $\operatorname{TrkB}$ and TrkB-T1 appear in close proximity to motor endplates in skeletal muscle. In contrast, a more recent study [49] using real-time PCR detected both the truncated and full-length TrkB mRNA in the predominantly fasttwitch medial gastrocnemius muscles. It is possible that the equivocal results regarding the expression of $\operatorname{TrkB}$ in skeletal muscle are due to methodological differences, because there are discrepant sensitivities between the sensitivity of techniques utilized to establish protein versus mRNA expression changes. Other studies have found the colocalization of TrkB with mitochondrial membrane [50] and endothelial cells
[51] in skeletal muscle, although the role of $\operatorname{TrkB}$ at these locations is not entirely understood.

Both GDNF receptor (GFR) $\alpha 1$ and GFR $\alpha 2$ are expressed abundantly in the developing and adult central and peripheral nervous systems $[52,53]$. GFR $\alpha 3$ mRNA was detected in spleen, lung, liver, heart, and kidney, but not in brain, skeletal muscle, or testis [54].

2.3. Neurotrophins at NMJs. Whether and if so how neurotrophins modulate the development and function of motor endplates in skeletal muscle has still not been fully elucidated. Neurotrophins have been shown to potentiate the spontaneous activity of developing neuromuscular synapses in culture $[55,56]$. The situation in vivo, however, is less clear. Overexpression of NT-4/5 in myoblasts in developing Xenopus laevis embryos leads to the enhanced release of acetylcholine in innervating motor terminals, and additional postsynaptic effects were observed with increased mean burst duration of low-conductance acetylcholine (ACh) receptor $(\mathrm{AChR})$ channels [57]. NT-4/5 overexpression in myocytes leads to the enhanced spontaneous activation of skeletal muscle [57]. This suggests that NT-4/5 modulates neuromuscular transmission and that this involves effects via pre- and postsynaptic TrkB receptors. Indeed, a more recent study [58] using confocal microscopy clearly demonstrated immunoreactivity to BDNF, NT-4/5, p75, and TrkB at NMJs in the mouse levator auris longus muscle.

Both BDNF and NT-4/5 acted on TrkB receptors in the pre- and postsynaptic part of the NMJ $[59,60]$. BDNF and NT-4/5 inhibited agrin-induced AChR clustering in cultured 
chicken myotubes, whereas NGF and NT-3 had no effect [60].

It was demonstrated that GDNF enhanced spontaneous neurotransmitter release in amphibian neuron-myocyte cocultures and isolated neuromuscular preparations from mice [61]. Treating frog neuron-muscle co-cultures with GDNF increased the frequency as well as amplitude of spontaneous synaptic currents [62]. In addition, using quantitative data from double-labeled imaging, Yang and Nelson [63] found that GDNF induced a quick and substantial increase in AChR insertion as well as lateral movement into AChR aggregates in the surface membrane of mouse primary cultured muscle cells. Furthermore, transgenic mice with muscle-specific overexpression of GDNF exhibit hyperinnervation of the muscle at birth and delayed synapse elimination [21]. Although all of the findings made in vitro and with transgenic mice show that GDNF plays an important role in the formation and maturation of NMJs, there is no direct evidence (e.g., immunofluorescence) that the GDNF protein exists at NMJs in normal mammalian skeletal muscle in vivo.

\section{Effect of Exercise on Neurotrophin and Neurotrophin Receptor Expression}

Increased physical activity has been shown to alter the structure and function of the NMJ. Exercise increases the size and degree of branching of motor nerve terminals at the NMJ [64], the total area of both pre- and postsynaptic elements [65], and the amount of ACh released [66]. Endurance exercise in young animals results in the hypertrophy of nerve terminals and an increase in neurotransmitter release [67]. Increased exercise training has also been shown to have effects on neurotrophic factor expression in mammalian skeletal muscle. BDNF mRNA expression has consistently been shown to increase in the CNS and peripheral nervous system (PNS) in a dose-dependent manner following exercise $[68,69]$. Recently, brief treadmill training bouts over 5 days were found to produce large increases in BDNF mRNA in soleus muscle $[70,71]$ that do not follow the positive dose-response relationship originally demonstrated in the nervous system with voluntary wheel running $[68,69,72$, 73]. As BDNF and NT- $4 / 5$ can initiate intracellular signaling through the same cell surface receptor, $\operatorname{TrkB}[74,75]$, it is of interest that NT-4/5 has not been evaluated following similar exercise. To date, only one study has addressed the issue of exercise-induced NT-4/5 expression, finding no significant elevation of NT-4/5 protein levels in the vastus lateralis of two aerobically trained individuals.

In Sprague-Dawley rats exercised on a treadmill at speeds of up to $20 \mathrm{~m} / \mathrm{min}$ with a $5 \%$ incline, BDNF mRNA expression was enhanced in soleus muscle following 5 days (184\%) but not 10 days of exercise. NT- $4 / 5$ and TrkB mRNA levels were not affected at either time point. The exercise-elicited increase in BDNF expression in muscle seems to influence neurotrophin levels in motoneurons. Gómez-Pinilla et al. [69] indicated a marked increase in BDNF mRNA but not protein in soleus muscle after 5 consecutive days of treadmill training. In contrast, ELISA and immunohistochemistry showed an increase in the protein but not mRNA in lumbar motoneurons after this training. It is known that motoneurons can retrogradely transport BDNF that has been injected into skeletal muscle [76] or the sciatic nerve $[77,78]$ and that the administration of BDNF can prevent the degeneration of motoneurons [76, 78]. These findings raise the question of whether these neurotrophic factors play a role in the routine maintenance and plasticity of the neuromuscular system.

Wehrwein et al. [43] showed that GDNF protein content increased with involuntary exercise in skeletal muscle but decreased with hindlimb suspension. This adaptation of GDNF protein content elicited by exercise seems to be dependent on muscle fiber type. More recently, McCullough et al. [79] found that low-intensity exercise $(10 \mathrm{~m} / \mathrm{min}$, $45 \mathrm{~min} /$ day, 2 weeks) increased and decreased the amount of GDNF in the soleus and EDL muscles, respectively, corresponding with the change in the average endplate area. Such a change in GDNF content was observed after both 4 hours of electrical stimulation and mechanical stretching in both muscles. Interestingly, pretreatment with $\alpha$-bungarotoxin blocked the stretch-induced decrease in GDNF protein in EDL muscle and uncovered a stretch-induced increase in the protein in soleus muscle. Therefore, ACh may act on nAChRs to regulate GDNF protein content. The application of GDNF increased spontaneous transmitter release from motor nerve terminals in skeletal muscles of both neonatal mice [61] and from nerve muscle co-cultures [62]. Treatment with exogeneous GDNF caused continuous synaptic remodeling and axonal branching at the NMJ [80]. Figure 2 provides an overview of molecular pathway of neurotrophic factors to regulate to neurotransmission, hypertrophy, or fat oxidation in skeletal muscle.

\section{Possible Role of Neurotrophins during Muscle Regeneration}

Experimental results indicate neurotrophins (particularly NGF) to be involved in muscle regeneration. NGF improved the muscle-regenerating capacity of muscle stem cells in dystrophic muscle [81]. In addition, phenotypic knockout of NGF resulted in skeletal muscle atrophy and dystrophy in adult mice $[6,82]$. In humans, regenerating muscle fibers from patients affected by Duchenne and Becker muscular dystrophies consistently express NGF, as do myofibroblasts and mast cells. Interestingly rest fibers from healthy subjects did not show NGF immunoreactivity or NGF protein [6]. Moreover, regenerating myofibers expressed NGF receptors, TrkA-receptor [83] as well as p75 ${ }^{\mathrm{NTR}}$ [84]. Taken together, these results indicate that, in dystrophic muscles, NGF expression might be able to trigger and favor the regeneration process. In fact, Deponti et al. [85] provided the direct evidence that NGF-p $75^{\text {NTR }}$ signaling regulates the differentiation of satellite cells in vivo. They utilized a tissue-permeable form of a NGF-competing peptide (P75 ${ }^{\text {NTR }}$ TAT4) or the control peptide TAT4 starting $48 \mathrm{~h}$ after damage (cardiotoxin injection). Six days after the cardiotoxin injection, regenerating centro-nucleated fibers 


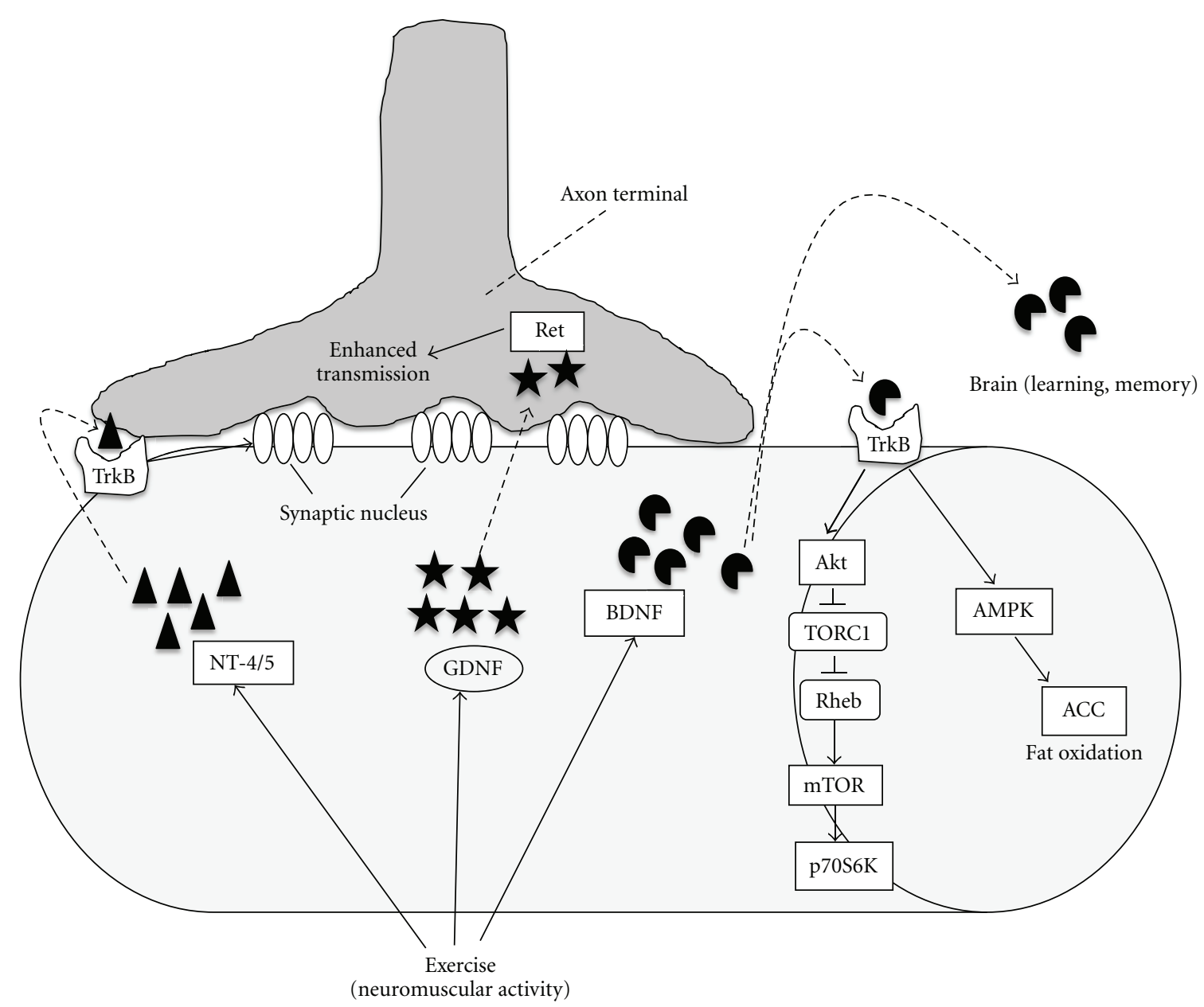

FIGURE 2: Schematic diagram of the functional role of skeletal muscle-derived neurotrophic factors after exercise. Exercise (neuromuscular activity) increases BDNF expression in skeletal muscle. In the patients with spinal cord injury, BDNF stimulates protein synthesis by activating Akt/mTOR/p70S6K pathway through TrkB receptor on muscle membrane. BDNF also promotes the fat oxidation through AMPKACC signaling. BDNF produced by skeletal muscle after exercise may circulate into brain to improve the impaired learning and/or depression. Increased GDNF protein after exercise promotes the amount of neurotransmitter (e.g., ACh) at NMJ by conjugating with Ret in presynaptic region (axon terminal). NT-4/5 may possess similar role of GDNF. BDNF: brain-derived neurotrophic factor, GDNF: glial cell-line derived neurotrophic factor, NT-4/5: neurotrophin-4/5, NMJ: neuromuscular junction, TORC1: a component of TOR signaling complex 1, Rheb: Ras homolog enriched in brain, mTOR: mammalian target of rapamycin, AMPK: AMP-activated protein kinase, and ACC: acetyl CoA carboxylase.

were present in the control, whereas no regeneration was apparent in the muscles treated with P75 ${ }^{\mathrm{NTR}} \mathrm{TAT} 4$. At 10 days, regeneration occurred also in the P75 ${ }^{\mathrm{NTR}} \mathrm{TAT} 4$-treated animals, however, it was significantly less extensive than in controls with a persistence of embryonic MHC. At this time, they observed the marked upregulation in RhoA-GTP expression in regenerating muscle treated with P75 ${ }^{\mathrm{NTR}} \mathrm{TAT} 4$ compared to control muscle. During muscle regeneration in vivo, NGF-p $75^{\mathrm{NTR}}$ signaling seems to promote myogenic differentiation by inhibiting RhoA-GTP as demonstrated in vitro using pull-down assays [85].

The role of BDNF in skeletal muscle development and function has been difficult to determine due in part to the early postnatal death of the BDNF knockout mouse (BDNF-/-)[86]. More recently, Clow and Jasmin [87] generated a mouse in which BDNF is specifically depleted from skeletal muscle cells to examine the functional role of muscle-derived BDNF in vivo. Mice carrying the LoxPtargeted BDNF allele $\left(\mathrm{BDNF}^{\mathrm{f} / \mathrm{f}}\right)$ were crossed with Myf5Cre mice to generate $\mathrm{BDNF}^{\mathrm{f} / \mathrm{wt}} ; \mathrm{Myf5}$-Cre progeny, and then backcrossed with $\mathrm{BDNF}^{\mathrm{f} / \mathrm{f}}$ homozygotes to produce $\mathrm{BDNF}^{\mathrm{f} / \mathrm{f}} ; \mathrm{Myf5}$-Cre mice $\left(\mathrm{BDNF}^{\mathrm{MKO}}\right)$. At $\mathrm{P} 7, \mathrm{BDNF}$ transcript levels were decreased by $\sim 50 \%$ in $\mathrm{BDNF}^{\mathrm{MKO}}$ muscles compared with controls. Although overall muscle histology is not affected in the absence of muscle-BDNF, they observed the decreased expression (by 30\%) of a satellite cell marker, Pax7. After the injection with cardiotoxin, BDNF-depleted muscle showed lower levels of differentiation-promoting factors such as myogenin, MyoD, and embryonic MHC as well as the delayed appearance of newly centrally nucleated fibers in the regenerating muscle during $1-5$ days [87]. Furthermore, treatment with exogeneous BDNF protein was 
sufficient to rescue normal gene expression and myotube size in $\mathrm{BDNF}^{\mathrm{MKO}}$ mice probably due to the upregulation of Pax7 expression.

In contrast, a previous study by this same group showed that siRNA-mediated depletion of BDNF resulted in the precocious differentiation of rat L6 myoblasts [35]. There are many possible causes for the disparity observed between these studies. First, there are intrinsic differences in the properties of immortalized cell lines and primary cultures. Second, the developmental timing of BDNF depletion differed between these studies. These differences, in conjunction with the different mechanisms used to deplete BDNF expression (siRNA transfection versus transgenic knockout) could result in altered responses of satellite cells to signals that promote growth, differentiation, or both. Finally, it becomes important to consider that many features of embryonic muscle development are recapitulated during muscle regeneration, with similar changes in muscle gene expression, physiological properties, and functional characteristics. In BDNF ${ }^{\mathrm{MKO}}$ muscle, Pax7 expression is decreased, satellite cell differentiation is defective, and regeneration is delayed.

GDNF signaling seems to have an important role during muscle regeneration. Using in situ hybridization histochemistry, Kami et al. [88] investigated whether the expression of GDNF-linked molecules significantly changes in regenerating muscle. They utilized muscle contusion to elicit extensive damage, because this approach directly damages muscle cells, blood vessels, intramuscular nerves, and extracellular matrix components. They found that muscle contusion induced increases in GDNF and GFR $\alpha 1$ mRNAs in Schwann celllike cells in the intramuscular nerves. GFR $\alpha 1$ and RET mRNA expression in motoneurons was upregulated. We have also observed such motoneuronal activation after muscle damage with bupivacaine [14]. Our immunoprecipitational analysis clearly showed the phosphorylation of TrkB in the spinal cord at 1 day after pharmacological muscle damage (bupivacaine). These findings suggest that a rapid and prominent increase in the receptor components for GDNF or TrkB in motoneurons is important for the regeneration of intramuscular motor nerves damaged by muscle contusion and bupivacaine injections.

\section{Neurotrophin and Neuromuscular Disorders}

5.1. Sarcopenia. Aging is associated with a progressive decline of muscle mass, quality, and strength, a condition known as sarcopenia [89]. Age-related muscle loss is a result of reductions in the size and number of muscle fibers possibly due to a multifactoral process that involves physical activity, nutritional intake, oxidative stress, and hormonal changes $[90,91]$. The specific contribution of each of these factors is unknown but there is emerging evidence that the disruption of several positive regulators (Akt and SRF (serum response factor)) of muscle hypertrophy with age is an important feature in the progression of sarcopenia [92-94]. In addition, marked motoneuron loss and aberrant neuromuscular sprouting have been observed in aged mammals. Neurotrophic factors expressed in skeletal muscle are essential to motoneuron survival and muscle fiber innervation during development. Spinal motoneurons express cognate receptors for these neurotrophic factors, and during aging, major changes take place in their expression pattern. Whereas the expression of TrkB and Trk $\mathrm{C}$ is downregulated, that of the components of the GDNF receptor (GFR $\alpha 1$ and Ret) is upregulated [95]. This pattern of regulation mirrors the altered expression of the corresponding neurotrophic factors in target muscles [22]. GDNF, one of the most potent neurotrophic factors for motoneurons, is markedly up-regulated in human as well as rat muscle tissue during aging [22]. In addition, muscle-derived CNTF receptor- $\alpha$ is considered to play an important role in muscle fiber innervation/reinnervation [96]. Edström et al. [97] showed increased levels of CNTF receptor- $\alpha$ in sarcopenic muscle compared with normal adult muscle. The increase in GDNF and CNTF receptor- $\alpha$ in sarcopenic muscles probably reflects signaling from regenerating/denervated muscle fibers to attract motor axons. Although this is evidence for increased GDNF signaling from muscle to motoneurons during aging, it is not sufficient to restore appropriate innervation of the muscle fibers.

5.2. Myopathies. As in animal models, pathological situations can modify neurotrophin expression. NGF concentrations were measured by enzyme immunoassay in muscle biopsies from subjects with amyotrophic lateral sclerosis (ALS) or inflammatory myopathies [13]. NGF levels were significantly (140\%) higher in patients with ALS than in the control subjects. In inflammatory myopathies, the increase was not significant. Age and gender had no influence on NGF concentrations in muscle. However, both mRNA and protein levels of NGF, BDNF, and NT-4/5 were increased in postmortem biopsies tissue of 15 ALS patients in comparison to controls, suggesting that some of the earlier data have to be reinvestigated and only biopsies from individuals with a postmortem period of less than $3 \mathrm{~h}$ should be tested [98]. During the course of the disease, upregulation of BDNF expression is observed in the early phase and the increase of NGF and NT-4/5, in later stages. In the spinal cord of ALS patients, a reduction in BDNF and no significant change in the amount of NT- $4 / 5$ were observed in spite of the elevated NGF expression. A decreased level of phosphorylated TrkB protein was also detected, suggesting impaired TrkB signaling [99]. Importantly, p $75^{\mathrm{NTR}}$ expression was induced in spinal cord motoneurons and denervated Schwann cells in ALS $[100,101]$. Collectively, these results suggest that motor neurons switch from BDNF to NGF responsiveness in human ALS. Systemic administration of a modified cyclic decapeptide $\mathrm{p} 75^{\mathrm{NTR}}$ antagonist conjugated to the TAT4 cell permeabilization sequence to presymptomatic transgenic SOD 1 ${ }^{\mathrm{G} 93 \mathrm{~A}}$ mice affected neither disease onset nor disease progression, as determined by hindlimb locomotion, grip strength, and survival [102].

In muscle from patients with DMD, NGF was expressed in regenerating fibers and connective tissue myofibroblast [103]. Rest fibers from dystrophic patients, as well as muscle fibers from healthy subjects and regenerative muscle fibers in patients with polymyositis (PM), did not show NGF 
immunoreactivity. In another study, NT- $4 / 5$ protein and mRNA were found in both type I and type II fibers of healthy aerobically trained athletes and patients with mitochondrial encephalomyopathies [40]. However, in ragged-red fibers, which are present more frequently in highly oxidative type I fibers than in glycolytic type II fibers of patients with mitochondrial encephalomyopathies, NT-4/5 expression is upregulated in contrast to muscle fibers from healthy subjects.

P75 ${ }^{\text {NTR }}$ expression has also been found in normal and pathological human muscle [84, 104]. Normal muscle cells from 12- to 22-week-old fetuses stained strongly for P75 ${ }^{\text {NTR }}$ [84]. In adult muscle, only intramuscular nerve endings showed immunoreactivity with no staining detected in muscle fibers [84]. The outer surface of some regenerating musclefibers, in muscle biopsy specimens from patients with muscular dystrophies, was positively stained for P75 ${ }^{\mathrm{NTR}}[84$, 104]. P75 ${ }^{\text {NTR }}$ mRNA expression was also detected using in situ hybridization in such cells.

Some muscular dystrophies would affect the amount of neurotrophin in the CNS as well as skeletal muscle. Our previous study [105] indicated the upregulation of GDNF protein and reciprocal downregulation of NT-4/5 protein in cerebellum and spinal cord motoneurons of merosindeficient $d y$ mice. In particular, our immunohistochemical analysis using $d y$ mice clearly showed the marked enhancement of GDNF protein in the Purkinje and granule cells of the cerebellum and in many lumbar motoneurons. At this time, the microtubule-associated protein-2 (MAP2) protein level was markedly decreased in these regions. Therefore, GDNF expression in the cerebellum and spinal cord appears to play a role in the fundamental disorders caused by a lack of merosin. Nico et al. [106] found marked immunoreactivity of NGF in neurons, astrocytes, and ependymal cells in the $m d x$ brain different to the faint NGF expression only in neurons and astrocytes. In addition, they demonstrated that $m d x$ brain possessed NGFRs on both glial and endothelial cells different to the absence of NGFR protein expression in endothelial cells in controls. Since some muscular dystrophies include a disorder of the CNS, elevated and/or decreased neurotrophin levels may further degrade the pathological symptoms.

5.3. Spinal Cord Injury. Spinal cord injury is a devastating neurological condition that produces muscular pareses/paralyses caudal to the lesion level, leading to a pronounced loss of muscle mass and severe muscle atrophy [107]. This paraplegia-induced muscle atrophy increases the risk of developing secondary health problems such as cardiovascular disease and diabetes in paraplegic patients [108]. Muscular disuse severely reduces the expression of BDNF protein and mRNA in both lumbar spinal cord and soleus muscle in acute and chronic stages after spinal cord injury. This trophic factor can activate rapamycin (mTOR), a protein that participates in mammalian cell size control and plays an important role in muscular tropism [109]. Furthermore, paraplegia-induced muscle atrophy in rats has been associated with a downregulation of the mTOR signaling pathway [110].
Studies have shown that repetitive motor activity, such as cycling exercise training, accelerates muscle size restoration after complete spinal cord injury in rats $[111,112]$. In addition, treadmill training has been shown to diminish the extent of muscle atrophy [107] and restores BDNF levels in both the lumbar spinal cord and soleus muscle [113] in moderate spinal cord injury models. Furthermore, more recently, Ilha et al. [114] conducted a 9-week stepprogram for rats with complete spinal cord transection (SCT) at T8-T9. Step training, initiated immediately after SCT in rats, partially reverted muscular atrophy in chronic paralyzed soleus muscle possibly due to BDNF upregulation. Therefore, BDNF produced in response to treadmill training appears to ameliorate the symptoms of spinal cord injuries.

5.4. Diabetes. BDNF has been identified as a key component of the hypothalamic pathway that controls body weight and energy homeostasis [115]. Most recently, Pederson et al. have shown that BDNF appears to be a major player not only in central metabolic pathways but also as a regulator of metabolism in skeletal muscle [13]. Interestingly, individuals with both obesity and type 2 diabetes possess low levels of circulating BDNF [116] similar to patients with Alzheimer's disease [117], major depression [118], or acute coronary syndrome [119]. In a human in vivo model, Pedersen et al. [120] demonstrated that the cerebral output of BDNF was inhibited under hyperglycemic clamp conditions. The latter finding may explain the concomitant finding of low circulating levels of BDNF in individuals with type 2 diabetes and the association between low plasma BDNF levels and the severity of insulin resistance [116]. The human data are in accordance with reports from animal models suggesting that BDNF also plays a role in insulin resistance and in energy balance. BDNF administration has beneficial effects on glucose homeostasis and improves insulin resistance in obese diabetic animal models, such as $\mathrm{C} 57 \mathrm{BL} / \mathrm{KsJ}-\mathrm{db} / \mathrm{db}$ mice, even when food intake is controlled $[121,122]$. It was found that BDNF mRNA and protein expression were increased in human skeletal muscle after exercise; however, muscle-derived BDNF appeared not to be released into the circulation. Since BDNF increased the phosphorylation of AMP-activated protein kinase (AMPK) and acetyl CoA carboxylase and enhanced fat oxidation both in vitro and ex vivo, contraction-induced muscle-derived BDNF may increase fat oxidation in an AMPK-dependent fashion.

\section{Conclusions}

This paper summarized and highlighted the current understanding of the normal distribution and functional role of neurotrophin in skeletal muscle during exercise, regeneration, and disorders. In particular, many researchers are interested in the important role of BDNF in learning and memory [123] or glucose metabolism as well as adaptations in skeletal muscle. A strategy for controlling the amount of BDNF may be also effective in the future treatment of various muscular disorders. 


\section{Acknowledgment}

This work was supported by a research Grant-in-Aid for Scientific Research C (no. 23500778) from the Ministry of Education, Science, Culture, Sports, Science and Technology of Japan.

\section{References}

[1] R. W. Oppenheim, "Cell death during development of the nervous system," Annual Review of Neuroscience, vol. 14, pp. 453-501, 1991.

[2] L. F. Reichardt, "Neurotrophin-regulated signalling pathways," Philosophical Transactions of the Royal Society B, vol. 361, no. 1473, pp. 1545-1564, 2006.

[3] O. Griesbeck, A. S. Parsadanian, M. Sendtner, and H. Thoenen, "Expression of neurotrophins in skeletal muscle: quantitative comparison and significance for motoneuron survival and maintenance of function," Journal of Neuroscience Research, vol. 42, no. 1, pp. 21-33, 1995.

[4] G. Chevrel, R. Hohlfeld, and M. Sendtner, "The role of neurotrophins in muscle under physiological and pathological conditions," Muscle and Nerve, vol. 33, no. 4, pp. 462-476, 2006.

[5] E. V. Pitts, S. Potluri, D. M. Hess, and R. J. BaliceGordon, "Neurotrophin and Trk-mediated signaling in the neuromuscular system," International Anesthesiology Clinics, vol. 44, no. 2, pp. 21-76, 2006.

[6] S. Capsoni, F. Ruberti, E. Di Daniel, and A. Cattaneo, "Muscular dystrophy in adult and aged anti-NGF transgenic mice resembles an inclusion body myopathy," Journal of Neuroscience Research, vol. 59, no. 4, pp. 553-560, 2000.

[7] D. I. Carrasco and A. W. English, "Neurotrophin 4/5 is required for the normal development of the slow muscle fiber phenotype in the rat soleus," Journal of Experimental Biology, vol. 206, no. 13, pp. 2191-2200, 2003.

[8] P. Ernfors, K. F. Lee, J. Kucera, and R. Jaenisch, "Lack of neurotrophin-3 leads to deficiencies in the peripheral nervous system and loss of limb proprioceptive afferents," Cell, vol. 77, no. 4, pp. 503-512, 1994.

[9] L. T. Ferris, J. S. Williams, and C. L. Shen, "The effect of acute exercise on serum brain-derived neurotrophic factor levels and cognitive function," Medicine and Science in Sports and Exercise, vol. 39, no. 4, pp. 728-734, 2007.

[10] S. Rojas Vega, H. K. Strüder, B. Vera Wahrmann, A. Schmidt, W. Bloch, and W. Hollmann, "Acute BDNF and cortisol response to low intensity exercise and following ramp incremental exercise to exhaustion in humans," Brain Research, vol. 1121, no. 1, pp. 59-65, 2006.

[11] S. M. Gold, K. H. Schulz, S. Hartmann et al., "Basal serum levels and reactivity of nerve growth factor and brain-derived neurotrophic factor to standardized acute exercise in multiple sclerosis and controls," Journal of Neuroimmunology, vol. 138, no. 1-2, pp. 99-105, 2003.

[12] V. B. Matthews, M. B. Åström, M. H. S. Chan et al., "Brainderived neurotrophic factor is produced by skeletal muscle cells in response to contraction and enhances fat oxidation via activation of AMP-activated protein kinase," Diabetologia, vol. 52, no. 7, pp. 1409-1418, 2009.

[13] H. J. Stuerenburg and K. Kunze, "Tissue nerve growth factor concentrations in neuromuscular diseases," European Journal of Neurology, vol. 5, no. 5, pp. 487-490, 1998.
[14] K. Sakuma, K. Watanabe, M. Sano et al., "A possible role for BDNF, NT-4 and TrkB in the spinal cord and muscle of rat subjected to mechanical overload, bupivacaine injection and axotomy," Brain Research, vol. 907, no. 1-2, pp. 1-19, 2001.

[15] P. Fernyhough, L. T. Diemel, W. J. Brewster, and D. R. Tomlinson, "Altered neurotrophin mRNA levels in peripheral nerve and skeletal muscle of experimentally diabetic rats," Journal of Neurochemistry, vol. 64, no. 3, pp. 1231-1237, 1995.

[16] P. Fernyhough, L. T. Diemel, J. Hardy, W. J. Brewster, L. Mohiuddin, and D. R. Tomlinson, "Human recombinant nerve growth factor replaces deficient neurotrophic support in the diabetic rat," European Journal of Neuroscience, vol. 7, no. 5, pp. 1107-1110, 1995.

[17] C. Ihara, A. Shimatsu, H. Mizuta, H. Murabe, Y. Nakamura, and K. Nakao, "Decreased neurotrophin-3 expression in skeletal muscles of streptozotocin-induced diabetic rats," Neuropeptides, vol. 30, no. 4, pp. 309-312, 1996.

[18] P. Fernyhough, L. T. Diemel, and D. R. Tomlinson, "Target tissue production and axonal transport of neurotrophin-3 are reduced in streptozocin-diabetic rats," Diabetologia, vol. 41, no. 3, pp. 300-306, 1998.

[19] P. Fernyhough, K. Maeda, and D. R. Tomlinson, "Brainderived neurotrophic factor mRNA levels are up-regulated in hindlimb skeletal muscle of diabetic rats: effects of denervation," Experimental Neurology, vol. 141, no. 2, pp. 297-303, 1996.

[20] L. F. H. Lin, D. H. Doherty, J. D. Lile, S. Bektesh, and F. Collins, "GDNF: a glial cell line-derived neurotrophic factor for midbrain dopaminergic neurons," Science, vol. 260, no. 5111, pp. 1130-1132, 1993.

[21] Q. T. Nguyen, A. S. Parsadanian, W. D. Snider, and J. W. Lichtman, "Hyperinnervation of neuromuscular junctions caused by GDNF overexpression in muscle," Science, vol. 279, no. 5357, pp. 1725-1729, 1998.

[22] B. Ulfhake, E. Bergman, E. Edström et al., "Regulation of neurotrophin signaling in aging sensory and motoneurons: dissipation of target support?" Molecular Neurobiology, vol. 21, no. 3, pp. 109-135, 2000.

[23] R. Klein, I. Silos-Santiago, R. J. Smeyne et al., "Disruption of the neurotrophin-3 receptor gene trkC eliminates Ia muscle afferents and results in abnormal movements," Nature, vol. 368, no. 6468, pp. 249-251, 1994.

[24] R. A. Oakley, F. B. Lefcort, D. O. Clary et al., "Neurotrophin3 promotes the differentiation of muscle spindle afferents in the absence of peripheral targets," Journal of Neuroscience, vol. 17, no. 11, pp. 4262-4274, 1997.

[25] D. E. Wright, L. Zhou, J. Kucera, and W. D. Snider, "Introduction of a neurotrophin-3 transgene into muscle selectively rescues proprioceptive neurons in mice lacking endogenous neurotrophin-3," Neuron, vol. 19, no. 3, pp. 503517, 1997.

[26] M. Simon, G. Terenghi, C. J. Green, and G. R. Coulton, "Differential effects of NT-3 on reinnervation of the fast extensor digitorum longus (EDL) and the slow soleus muscle of rat," European Journal of Neuroscience, vol. 12, no. 3, pp. 863-871, 2000.

[27] G. D. Sterne, G. R. Coulton, R. A. Brown, C. J. Green, and G. Terenghi, "Neurotrophin-3-enhanced nerve regeneration selectively improves recovery of muscle fibers expressing myosin heavy chains 2b," Journal of Cell Biology, vol. 139, no. 3, pp. 709-715, 1997. 
[28] F. C. F. Ip, J. Cheung, and N. Y. Ip, “The expression profiles of neurotrophins and their receptors in rat and chicken tissues during development," Neuroscience Letters, vol. 301, no. 2, pp. 107-110, 2001.

[29] V. E. Koliatsos, M. H. Cayouette, L. R. Berkemeier, R. E. Clatterbuck, D. L. Price, and A. Rosenthal, "Neurotrophin $4 / 5$ is a trophic factor for mammalian facial motor neurons," Proceedings of the National Academy of Sciences of the United States of America, vol. 91, no. 8, pp. 3304-3308, 1994.

[30] V. E. Koliatsos, R. E. Clatterbuck, J. W. Winslow, M. H. Cayouette, and D. L. Price, "Evidence that brain-derived neurotrophic factor is a trophic factor for motor neurons in vivo," Neuron, vol. 10, no. 3, pp. 359-367, 1993.

[31] P. C. Maisonpierre, L. Belluscio, B. Friedman et al., "NT3, BDNF, and NGF in the developing rat nervous system: parallel as well as reciprocal patterns of expression," Neuron, vol. 5, no. 4, pp. 501-509, 1990.

[32] T. Timmusk, N. Belluardo, M. Metsis, and H. Persson, "Widespread and developmentally regulated expression of neurotrophin-4 mRNA in rat brain and peripheral tissues," European Journal of Neuroscience, vol. 5, no. 6, pp. 605-613, 1993.

[33] L. C. Schecterson and M. Bothwell, "Novel roles for neurotrophins are suggested by BDNF and NT-3 mRNA expression in developing neurons," Neuron, vol. 9, no. 3, pp. 449-463, 1992.

[34] S. Liem, N. Brouwer, and J. C. Copray, "Ultrastructural localization of intramuscular expression of BDNF mRNA by siver-gold intensified non-radioactive in situ hybridization," Histochemistry and Cell Biology, vol. 116, pp. 545-551, 2001.

[35] K. Mousavi and B. J. Jasmin, "BDNF is expressed in skeletal muscle satellite cells and inhibits myogenic differentiation," Journal of Neuroscience, vol. 26, no. 21, pp. 5739-5749, 2006.

[36] R. W. Oppenheim, Y. Qin-Wei, D. Prevette, and Q. Yan, "Brain-derived neurotrophic factor rescues developing avian motoneurons from cell death," Nature, vol. 360, no. 6406, pp. 755-757, 1992.

[37] X. H. Zhang and M. M. Poo, "Localized synaptic potentiation by BDNF requires local protein synthesis in the developing axon," Neuron, vol. 36, no. 4, pp. 675-688, 2002.

[38] K. Mousavi, D. J. Parry, and B. J. Jasmin, "BDNF rescues myosin heavy chain IIB muscle fibers after neonatal nerve injury," American Journal of Physiology, vol. 287, no. 1, pp. C22-C29, 2004.

[39] H. Funakoshi, N. Belluardo, E. Arenas et al., "Muscle-derived neurotrophin-4 as an activity-dependent trophic signal for adult motor neurons," Science, vol. 268, no. 5216, pp. 14951499, 1995.

[40] U. A. Walker and E. A. Schon, "Neurotrophin-4 is upregulated in ragged-red fibers associated with pathogenic mitochondrial DNA mutations," Annals of Neurology, vol. 43, no. 4, pp. 536-540, 1998.

[41] C. E. Henderson, H. S. Phillips, R. A. Pollock et al., "GDNF: a potent survival factor for motoneurons present in peripheral nerve and muscle," Science, vol. 266, no. 5187, pp. 1062-1064, 1994.

[42] H. Suzuki, A. Hase, Y. Miyata, K. Arahata, and C. Akazawa, "Prominent expression of glial cell line-derived neurotrophic factor in human skeletal muscle," Journal of Comparative Neurology, vol. 402, no. 3, pp. 303-312, 1998.

[43] E. A. Wehrwein, E. M. Roskelley, and J. M. Spitsbergen, "GDNF is regulated in an activity-dependent manner in rat skeletal muscle," Muscle and Nerve, vol. 26, no. 2, pp. 206$211,2002$.
[44] P. Ernfors, F. Hallbook, T. Ebendal et al., "Developmental and regional expression of $\beta$-nerve growth factor receptor mRNA in the chick and rat," Neuron, vol. 1, no. 10, pp. 983-996, 1988.

[45] C. Lomen-Hoerth and E. M. Shooter, "Widespread neurotrophin receptor expression in the immune system and other nonneuronal rat tissues," Journal of Neurochemistry, vol. 64 , no. 4, pp. 1780-1789, 1995.

[46] M. Yamamoto, G. Sobue, K. Yamamoto, S. Terao, and T. Mitsuma, "Expression of mRNAs for neurotrophic factors (NGF, BDNF, NT-3, and GDNF) and their receptors (p75NGFR, $\operatorname{TrkA}$, TrkB, and TrkC) in the adult human peripheral nervous system and nonneural tissues," Neurochemical Research, vol. 21, no. 8, pp. 929-938, 1996.

[47] J. G. Heuer, C. S. von Bartheld, Y. Kinoshita, P. C. Evers, and M. Bothwell, "Alternating phases of FGF receptor and NGF receptor expression in the developing chicken nervous system," Neuron, vol. 5, no. 3, pp. 283-296, 1990.

[48] R. Klein, "Role of neurotrophins in mouse neuronal development," The FASEB Journal, vol. 8, no. 10, pp. 738-744, 1994.

[49] D. I. Ogborn and P. F. Gardiner, "Effects of exercise and muscle type on BDNF, NT-4/5, and TrKB expression in skeletal muscle," Muscle and Nerve, vol. 41, no. 3, pp. 385$391,2010$.

[50] F. R. Wiedemann, D. Siemen, C. Mawrin, T. F. Horn, and K. Dietzmann, "The neurotrophin receptor TrkB is colocalized to mitochondrial membranes," International Journal of Biochemistry and Cell Biology, vol. 38, no. 4, pp. 610-620, 2006.

[51] P. Kermani, D. Rafii, D. K. Jin et al., "Neurotrophins promote revascularization by local recruitment of $\operatorname{TrkB}+$ endothelial cells and systemic mobilization of hematopoietic progenitors," The Journal of Clinical Investigation, vol. 115, no. 3, pp. 653-663, 2005.

[52] J. Widenfalk, C. Nosrat, A. Tomac, H. Westphal, B. Hoffer, and L. Olson, "Neurturin and glial cell line-derived neurotrophic factor receptor- $\beta$ (GDNFR- $\beta$ ), novel proteins related to GDNF and GDNFR- $\alpha$ with specific cellular patterns of expression suggesting roles in the developing and adult nervous system and in peripheral organs," Journal of Neuroscience, vol. 17, no. 21, pp. 8506-8519, 1997.

[53] P. Naveilhan, C. Baudet, A. Mikaels, L. Shen, H. Westphal, and P. Ernfors, "Expression and regulation of GFR $\alpha 3$, a glial cell line-derived neurotrophic factor family receptor," Proceedings of the National Academy of Sciences of the United States of America, vol. 95, no. 3, pp. 1295-1300, 1998.

[54] S. Jing, Y. Yu, M. Fang et al., "GFR $\alpha-2$ and GFR $\alpha-3$ are two new receptors for ligands of the GDNF family," The Journal of Biological Chemistry, vol. 272, no. 52, pp. 33111-33117, 1997.

[55] R. J. Kleiman, N. Tian, D. Krizaj, T. N. Hwang, D. R. Copenhagen, and L. F. Reichardt, "BDNF-induced potentiation of spontaneous twitching in innervated myocytes requires calcium release from intracellular stores," Journal of Neurophysiology, vol. 84, no. 1, pp. 472-483, 2000.

[56] R. Stoop and M. M. Poo, "Synaptic modulation by neurotrophic factors: differential and synergistic effects of brainderived neurotrophic factor and ciliary neurotrophic factor," Journal of Neuroscience, vol. 16, no. 10, pp. 3256-3264, 1996.

[57] X. H. Wang and M. M. Poo, "Potentiation of developing synapses by postsynaptic release of neurotrophin-4," Neuron, vol. 19 , no. 4, pp. 825-835, 1997.

[58] N. Garcia, M. Tomàs, M. M. Santafe, M. A. Lanuza, N. Besalduch, and J. Tomàs, "Localization of brain-derived neurotrophic factor, neurotrophin-4, tropomyosin-related kinase $\mathrm{b}$ receptor, and $\mathrm{p} 75 \mathrm{NTR}$ receptor by high-resolution 
immunohistochemistry on the adult mouse neuromuscular junction," Journal of the Peripheral Nervous System, vol. 15, no. 1, pp. 40-49, 2010.

[59] A. K. Y. Fu, F. C. F. Ip, K. O. Lai, K. W. K. Tsim, and N. Y. Ip, "Muscle-derived neurotrophin-3 increases the aggregation of acetylcholine receptors in neuron-muscle co-cultures," NeuroReport, vol. 8, no. 18, pp. 3895-3900, 1997.

[60] D. G. Wells, B. A. Mckechnie, S. Kelkar, and J. R. Fallon, "Neurotrophins regulate agrin-induced postsynaptic differentiation," Proceedings of the National Academy of Sciences of the United States of America, vol. 96, no. 3, pp. 1112-1117, 1999.

[61] R. R. Ribchester, D. Thomson, L. J. Haddow, and Y. A. Ushkaryov, "Enhancement of spontaneous transmitter release at neonatal mouse neuromuscular junctions by the glial cell line-derived neurotrophic factor (GDNF)," Journal of Physiology, vol. 512, no. 3, pp. 635-641, 1998.

[62] C. Y. Wang, F. Yang, X. P. He et al., "Regulation of neuromuscular synapse development by glial cell line-derived neurotrophic factor and neurturin," The Journal of Biological Chemistry, vol. 277, no. 12, pp. 10614-10625, 2002.

[63] L. X. Yang and P. G. Nelson, "Glia cell line-derived neurotrophic factors regulates the distribution of acetylcholine receptors in mouse primary skeletal muscle cells," Neuroscience, vol. 128, no. 3, pp. 497-509, 2004.

[64] M. H. Andonian and M. A. Fahim, "Effects of endurance exercise on the morphology of mouse neuromuscular junction during ageing," Journal of Neurocytology, vol. 16, no. 5, pp. 589-599, 1987.

[65] M. R. Deschenes, C. M. Maresh, J. F. Crivello, L. E. Armstrong, W. J. Kraemer, and J. Covault, "The effects of exercise training of different intensities on neuromuscular junction morphology," Journal of Neurocytology, vol. 22, no. 8, pp. 603-615, 1993.

[66] M. Dorlochter, A. Irintchev, M. Brinkers, and A. Wernig, "Effects of enhanced activity on synaptic transmission in mouse extensor digitorum longus muscle," Journal of Physiology, vol. 436, pp. 283-292, 1991.

[67] M. A. Fahim, "Endurance exercise modulates neuromuscular junction of C57BL/6NNia aging mice," Journal of Applied Physiology, vol. 83, no. 1, pp. 59-66, 1997.

[68] P. A. Adlard, V. M. Perreau, C. Engesser-Cesar, and C. W. Cotman, "The timecourse of induction of brain-derived neurotrophic factor mRNA and protein in the rat hippocampus following voluntary exercise," Neuroscience Letters, vol. 363, no. 1, pp. 43-48, 2004.

[69] F. Gómez-Pinilla, Z. Ying, R. R. Roy, R. Molteni, and V. R. Edgerton, "Voluntary exercise induces a BDNF-mediated mechanism that promotes neuroplasticity," Journal of Neurophysiology, vol. 88, no. 5, pp. 2187-2195, 2002.

[70] R. Cuppinf, S. Sartini, D. Agostini et al., "BDNF expression in rat skeletal muscle after acute or repeated exercise," Archives Italiennes de Biologie, vol. 145, no. 2, pp. 99-110, 2007.

[71] F. Gómez-Pinilla, Z. Ying, P. Opazo, R. R. Roy, and V. R. Edgerton, "Differential regulation by exercise of BDNF and NT-3 in rat spinal cord and skeletal muscle," European Journal of Neuroscience, vol. 13, no. 6, pp. 1078-1084, 2001.

[72] S. A. Neeper, F. Gómez-Pinilla, J. Choi, and C. Cotman, "Exercise and brain neurotrophins," Nature, vol. 373, no. 6510, article 109, 1995.

[73] H. S. Oliff, N. C. Berchtold, P. Isackson, and C. W. Cotman, "Exercise-induced regulation of brain-derived neurotrophic factor (BDNF) transcripts in the rat hippocampus," Molecular Brain Research, vol. 61, no. 1-2, pp. 147-153, 1998.
[74] R. Klein, F. Lamballe, S. Bryant, and M. Barbacid, "The trkB tyrosine protein kinase is a receptor for neurotrophin-4," Neuron, vol. 8, no. 5, pp. 947-956, 1992.

[75] R. Klein, V. Nanduri, S. Jing et al., "The trkB tyrosine protein kinase is a receptor for brain-derived neurotrophic factor and neurotrophin-3," Cell, vol. 66, no. 2, pp. 395-403, 1991.

[76] Y. Sagot, T. Rossé, R. Vejsada, D. Perrelet, and A. C. Kato, "Differential effects of neurotrophic factors on motoneuron retrograde labeling in a murine model of motoneuron disease," Journal of Neuroscience, vol. 18, no. 3, pp. 11321141, 1998.

[77] R. Curtis, J. R. Tonra, J. L. Stark et al., "Neuronal injury increases retrograde axonal transport of the neurotrophins to spinal sensory neurons and motor neurons via multiple receptor mechanisms," Molecular and Cellular Neurosciences, vol. 12, no. 3, pp. 105-118, 1998.

[78] Q. Yan, J. Elliott, and W. D. Snider, "Brain-derived neurotrophic factor rescues spinal motor neurons from axotomy-induced cell death," Nature, vol. 360, no. 6406, pp. 753-755, 1992.

[79] M. J. McCullough, N. G. Peplinski, K. R. Kinnell, and J. M. Spitsbergen, "Glial cell line-derived neurotrophic factor protein content in rat skeletal muscle is altered by increased physical activity in vivo and in vitro," Neuroscience, vol. 174, pp. 234-244, 2011.

[80] C. R. Keller-Peck, G. Feng, J. R. Sanes, Q. Yan, J. W. Lichtman, and W. D. Snider, "Glial cell line-derived neurotrophic factor administration in postnatal life results in motor unit enlargement and continuous synaptic remodeling at the neuromuscular junction," Journal of Neuroscience, vol. 21, no. 16, pp. 6136-6146, 2001.

[81] M. Lavasani, A. Lu, H. Peng, J. Cummins, and J. Huard, "Nerve growth factor improves the muscle regeneration capacity of muscle stem cells in dystrophic muscle," Human Gene Therapy, vol. 17, no. 2, pp. 180-192, 2006.

[82] F. Ruberti, S. Capsoni, A. Comparini et al., "Phenotypic knockout of nerve growth factor in adult transgenic mice reveals severe deficits in basal forebrain cholinergic neurons, cell death in the spleen, and skeletal muscle dystrophy," Journal of Neuroscience, vol. 20, no. 7, pp. 2589-2601, 2000.

[83] M. Rende, E. Brizi, J. Conner et al., "Nerve growth factor (NGF) influences differentiation and proliferation of myogenic cells in vitro via TrKA," International Journal of Developmental Neuroscience, vol. 18, no. 8, pp. 869-885, 2000.

[84] P. Baron, E. Scarpini, G. Meola et al., "Expression of the lowaffinity NGF receptor during human muscle development, regeneration, and in tissue culture," Muscle and Nerve, vol. 17, no. 3, pp. 276-284, 1994.

[85] D. Deponti, R. Buono, G. Catanzaro et al., "The low-affinity receptor for neurotrophins p75NTR plays a key role for satellite cell function in muscle repair acting via RhoA," Molecular Biology of the Cell, vol. 20, no. 16, pp. 3620-3627, 2009.

[86] P. Ernfors, K. F. Lee, and R. Jaenisch, "Mice lacking brainderived neurotrophic factor develop with sensory deficits," Nature, vol. 368, no. 6467, pp. 147-150, 1994.

[87] C. Clow and B. J. Jasmin, "Brain-derived neurotrophic factor regulates satellite cell differentiation and skeltal muscle regeneration," Molecular Biology of the Cell, vol. 21, no. 13, pp. 2182-2190, 2010.

[88] K. Kami, Y. Morikawa, Y. Kawai, and E. Senba, "Leukemia inhibitory factor, glial cell line-derived neurotrophic factor, and their receptor expressions following muscle crush 
injury," Muscle and Nerve, vol. 22, no. 11, pp. 1576-1586, 1999.

[89] D. G. Candow and P. D. Chilibeck, "Differences in size, strength, and power of upper and lower body muscle groups in young and older men," Journals of Gerontology-Series A Biological Sciences and Medical Sciences, vol. 60, no. 2, pp. 148-156, 2005.

[90] R. N. Baumgartner, D. L. Waters, D. Gallagher, J. E. Morley, and P. J. Garry, "Predictors of skeletal muscle mass in elderly men and women," Mechanisms of Ageing and Development, vol. 107, no. 2, pp. 123-136, 1999.

[91] R. Roubenoff and V. A. Hughes, "Sarcopenia: current concepts," Journals of Gerontology-Series A Biological Sciences and Medical Sciences, vol. 55, no. 12, pp. M716-M724, 2000.

[92] K. Sakuma, M. Akiho, H. Nakashima, H. Akima, and M. Yasuhara, "Age-related reductions in expression of serum response factor and myocardin-related transcription factor $\mathrm{A}$ in mouse skeletal muscles," Biochimica et Biophysica Acta, vol. 1782, no. 7-8, pp. 453-461, 2008.

[93] K. Sakuma and A. Yamaguchi, "Molecular mechanisms in aging and current strategies to counteract sarcopenia," Current Aging Science, vol. 3, no. 2, pp. 90-101, 2010.

[94] K. Sakuma and A. Yamaguchi, "Sarcopenia: molecular mechanisms and current therapeutic strategy," in Cell Aging, J. W. Perloft and A. H. Wong, Eds., Nova Science, Huntington, NY, USA, 2011.

[95] H. Johnson, K. Mossberg, U. Arvidsson, F. Piehl, T. Hökfelt, and B. Ulfhake, "Increase in $\alpha$-CGRP and GAP-43 in aged motoneurons: a study of peptides, growth factors, and ChAT mRNA in the lumbar spinal cord of senescent rats with symptoms of hindlimb incapacities," Journal of Comparative Neurology, vol. 359, no. 1, pp. 69-89, 1995.

[96] T. M. DeChiara, R. Vejsada, W. T. Poueymirou et al., "Mice lacking the CNTF receptor, unlike mice lacking CNTF, exhibit profound motor neuron deficits at birth," Cell, vol. 83, no. 2, pp. 313-322, 1995.

[97] E. Edström, M. Altun, E. Bergman et al., "Factors contributing to neuromuscular impairment and sarcopenia during aging," Physiology and Behavior, vol. 92, no. 1-2, pp. 129-135, 2007.

[98] B. M. Küst, J. C. V. M. Copray, N. Brouwer, D. Troost, and H. W. G. M. Boddeke, "Elevated levels of neurotrophins in human biceps brachii tissue of amyotrophic lateral sclerosis," Experimental Neurology, vol. 177, no. 2, pp. 419-427, 2002.

[99] T. Mutoh, G. Sobue, T. Hamano et al., "Decreased phosphorylation levels of TrkB neurotrophin receptor in the spinal cords from patients with amyotrophic lateral sclerosis," Neurochemical Research, vol. 25, no. 2, pp. 239-245, 2000.

[100] H. Kerkhoff, F. G. I. Jennekens, D. Troost, and H. Veldman, "Nerve growth factor receptor immunostaining in the spinal cord and peripheral nerves in amyotrophic lateral sclerosis," Acta Neuropathologica, vol. 81, no. 6, pp. 649-656, 1991.

[101] J. L. Seeburger, S. Tarras, H. Natter, and J. E. Springer, "Spinal cord motoneurons express p75(NGFR) and p145(trkB) mRNA in amyotrophic lateral sclerosis," Brain Research, vol. 621, no. 1, pp. 111-115, 1993.

[102] B. J. Turner, S. S. Murray, L. G. Piccenna, E. C. Lopes, T. J. Kilpatrick, and S. S. Cheema, "Effect of p75 neurotrophin receptor antagonist on disease progression in transgenic amyotrophic lateral sclerosis mice," Journal of Neuroscience Research, vol. 78, no. 2, pp. 193-199, 2004.

[103] P. Toti, M. Villanova, R. Vatti et al., "Nerve growth factor expression in human dystrophic muscles," Muscle and Nerve, vol. 27, no. 3, pp. 370-373, 2003.
[104] J. Zhao, K. Yoshioka, T. Miike, T. Kageshita, and T. Arao, "Nerve growth factor receptor immunoreactivity on the tunica adventitia of intramuscular blood vessels in childhood muscular dystrophies," Neuromuscular Disorders, vol. 1, no. 2, pp. 135-141, 1991.

[105] K. Sakuma, K. Watanabe, T. Totsuka et al., "The reciprocal change of neurotrophin-4 and glial cell line-derived neurotrophic factor protein in the muscles, spinal cord and cerebellum of the dy mouse," Acta Neuropathologica, vol. 104, no. 5, pp. 482-492, 2002.

[106] B. Nico, D. Mangieri, A. De Luca et al., "Nerve growth factor and its receptors TrkA and p75 are upregulated in the brain of mdx dystrophic mouse," Neuroscience, vol. 161, no. 4, pp. 1057-1066, 2009.

[107] J. E. Stevens, M. Liu, P. Bose et al., "Changes in soleus muscle function and fiber morphology with one week of locomotor training in spinal cord contusion injured rats," Journal of Neurotrauma, vol. 23, no. 11, pp. 1671-1681, 2006.

[108] A. P. Buunk, R. Zurriaga, P. Gonzalez, C. Terol, and S. L. Roig, "Targets and dimensions of social comparison among people with spinal cord injury and other health problems," British Journal of Health Psychology, vol. 11, no. 4, pp. 677-693, 2006.

[109] S. C. Bodine, T. N. Stitt, M. Gonzalez et al., "Akt/mTOR pathway is a crucial regulator of skeletal muscle hypertrophy and can prevent muscle atrophy in vivo," Nature Cell Biology, vol. 3, no. 11, pp. 1014-1019, 2001.

[110] H. C. Dreyer, E. L. Glynn, H. L. Lujan, C. S. Fry, S. E. DiCarlo, and B. B. Rasmussen, "Chronic paraplegia-induced muscle atrophy downregulates the mTOR/S6K1 signaling pathway," Journal of Applied Physiology, vol. 104, no. 1, pp. 27-33, 2008.

[111] E. E. Dupont-Versteegden, R. J. L. Murphy, J. D. Houlé, C. M. Gurley, and C. A. Peterson, "Mechanisms leading to restoration of muscle size with exercise and transplantation after spinal cord injury," American Journal of Physiology, vol. 279, no. 6, pp. C1677-C1684, 2000.

[112] J. M. Nothias, T. Mitsui, J. S. Shumsky, I. Fischer, M. D. Antonacci, and M. Murray, "Combined effects of neurotrophin secreting transplants, exercise, and serotonergic drug challenge improve function in spinal rats," Neurorehabilitation and Neural Repair, vol. 19, no. 4, pp. 296-312, 2005.

[113] K. J. Hutchinson, F. Gómez-Pinilla, M. J. Crowe, Z. Ying, and D. M. Basso, "Three exercise paradigms differentially improve sensory recovery after spinal cord contusion in rats," Brain, vol. 127, no. 6, pp. 1403-1414, 2004.

[114] J. Ilha, N. B. da Cunha, M. Jaeger et al., "Treadmill step training-induced adaptive muscular plasticity in a chronic paraplegia model," Neuroscience Letters, vol. 492, no. 3, pp. 170-174, 2011.

[115] B. E. Wisse and M. W. Schwartz, "The skinny on neurotrophins," Nature Neuroscience, vol. 6, no. 7, pp. 655-656, 2003.

[116] K. S. Krabbe, A. R. Nielsen, R. Krogh-Madsen et al., "Brainderived neurotrophic factor (BDNF) and type 2 diabetes," Diabetologia, vol. 50, no. 2, pp. 431-438, 2007.

[117] C. Laske, E. Stransky, T. Leyhe et al., "Stage-dependent BDNF serum concentrations in Alzheimer's disease," Journal of Neural Transmission, vol. 113, no. 9, pp. 1217-1224, 2006.

[118] F. Karege, G. Perret, G. Bondolfi, M. Schwald, G. Bertschy, and J. M. Aubry, "Decreased serum brain-derived neurotrophic factor levels in major depressed patients," Psychiatry Research, vol. 109, no. 2, pp. 143-148, 2002.

[119] L. Manni, V. Nikolova, D. Vyagova, G. N. Chaldakov, and L. Aloe, "Reduced plasma levels of NGF and BDNF in patients 
with acute coronary syndromes," International Journal of Cardiology, vol. 102, no. 1, pp. 169-171, 2005.

[120] B. K. Pedersen, M. Pedersen, K. S. Krabbe, H. Bruunsgaard, V. B. Matthews, and M. A. Febbraio, "Role of exerciseinduced brain-derived neurotrophic factor production in the regulation of energy homeostasis in mammals: experimental Physiology-Hot Topic Review," Experimental Physiology, vol. 94, no. 12, pp. 1153-1160, 2009.

[121] T. Nakagawa, A. Tsuchida, Y. Itakura et al., "Brain-derived neurotrophic factor regulates glucose metabolism by modulating energy balance in diabetic mice," Diabetes, vol. 49, no. 3, pp. 436-444, 2000.

[122] J. R. Tonra, M. Ono, X. Liu et al., "Brain-derived neurotrophic factor improves blood glucose control and alleviates fasting hyperglycemia in C57BLKS-Lepr(db)/lepr(db) mice," Diabetes, vol. 48, no. 3, pp. 588-594, 1999.

[123] Y. F. Liu, H. I. Chen, C. L. Wu et al., "Differential effects of treadmill running and wheel running on spatial or aversive learning and memory: roles of amygdalar brainderived neurotrophic factor and synaptotagmin I," Journal of Physiology, vol. 587, no. 13, pp. 3221-3231, 2009. 

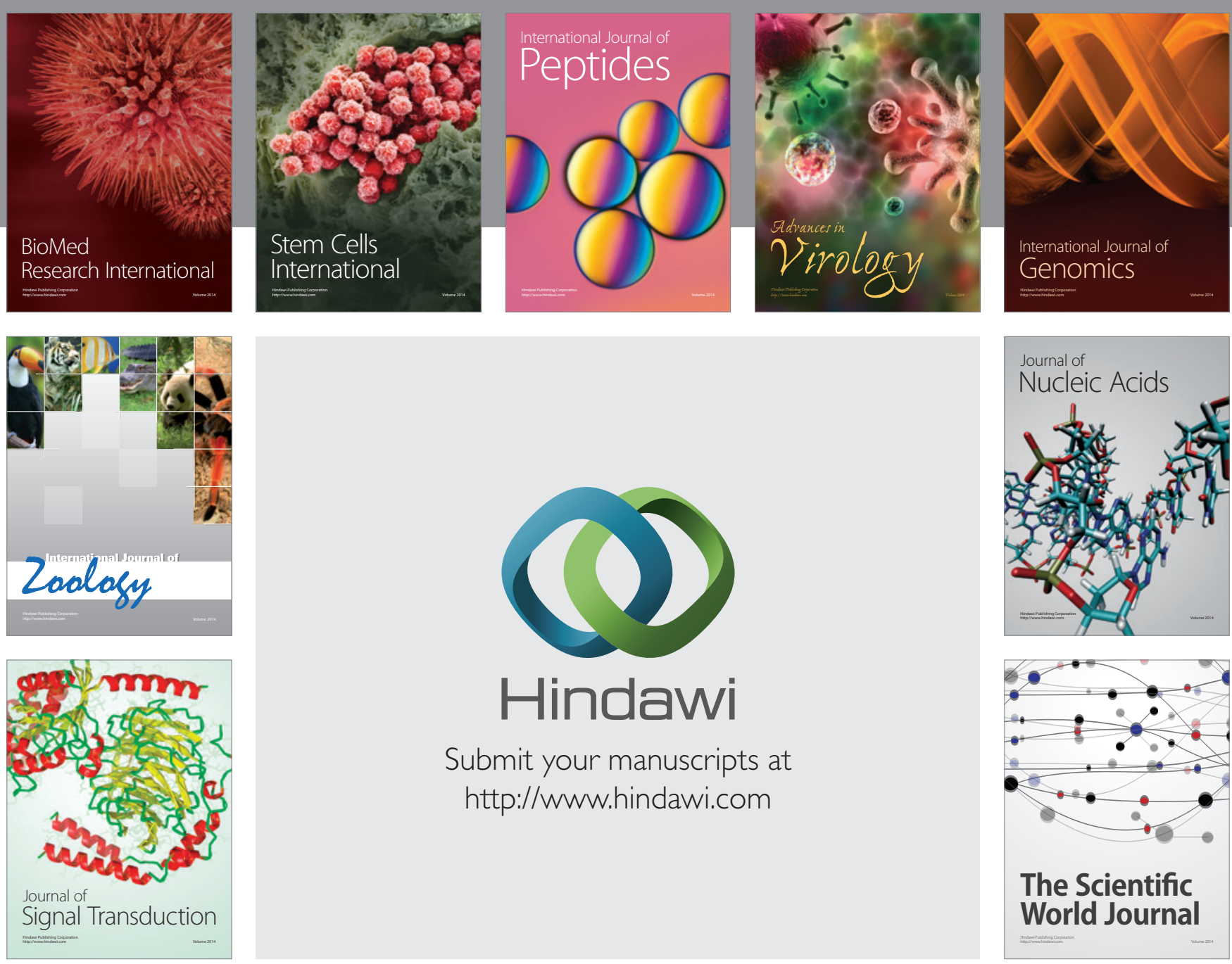

Submit your manuscripts at

http://www.hindawi.com
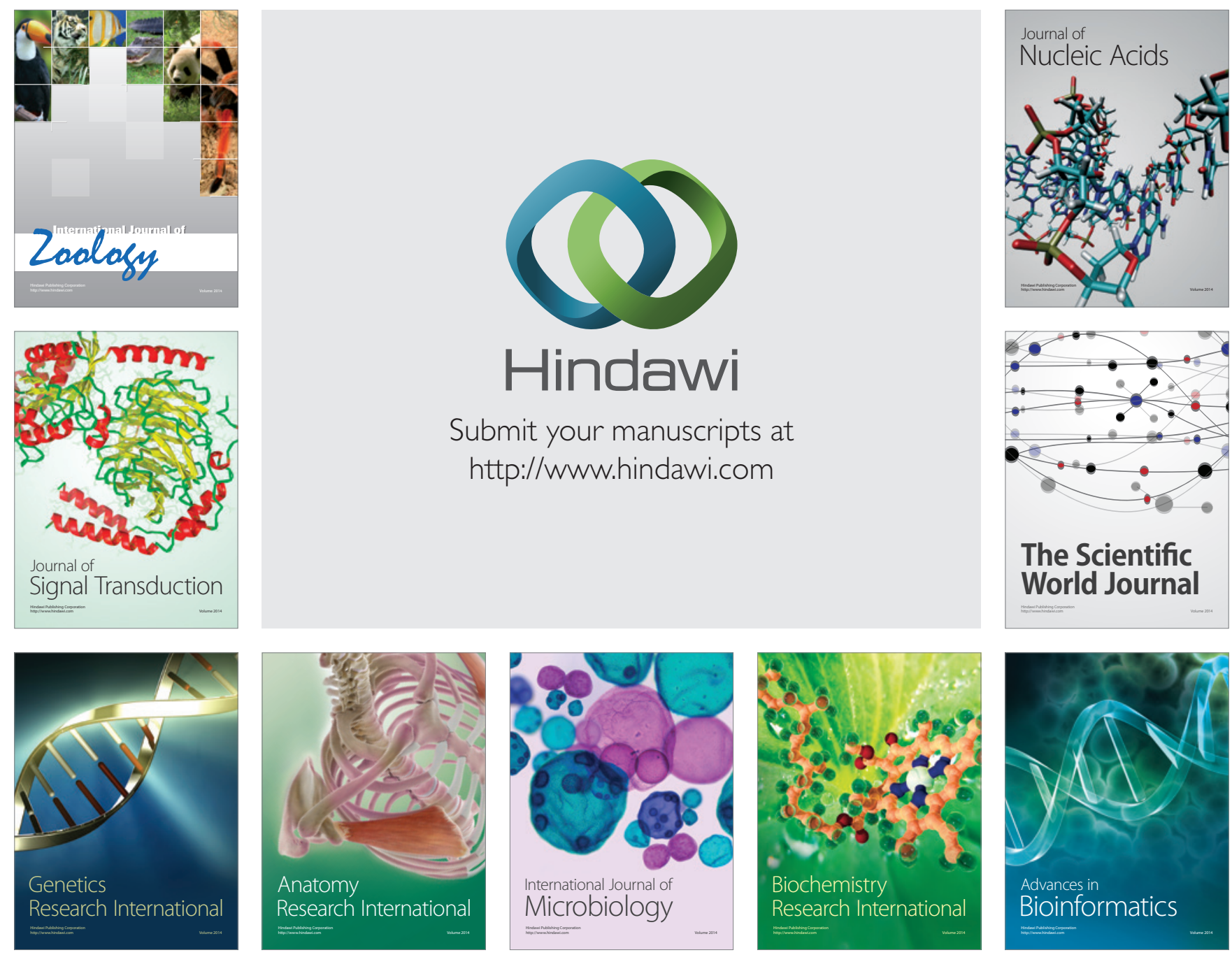

The Scientific World Journal
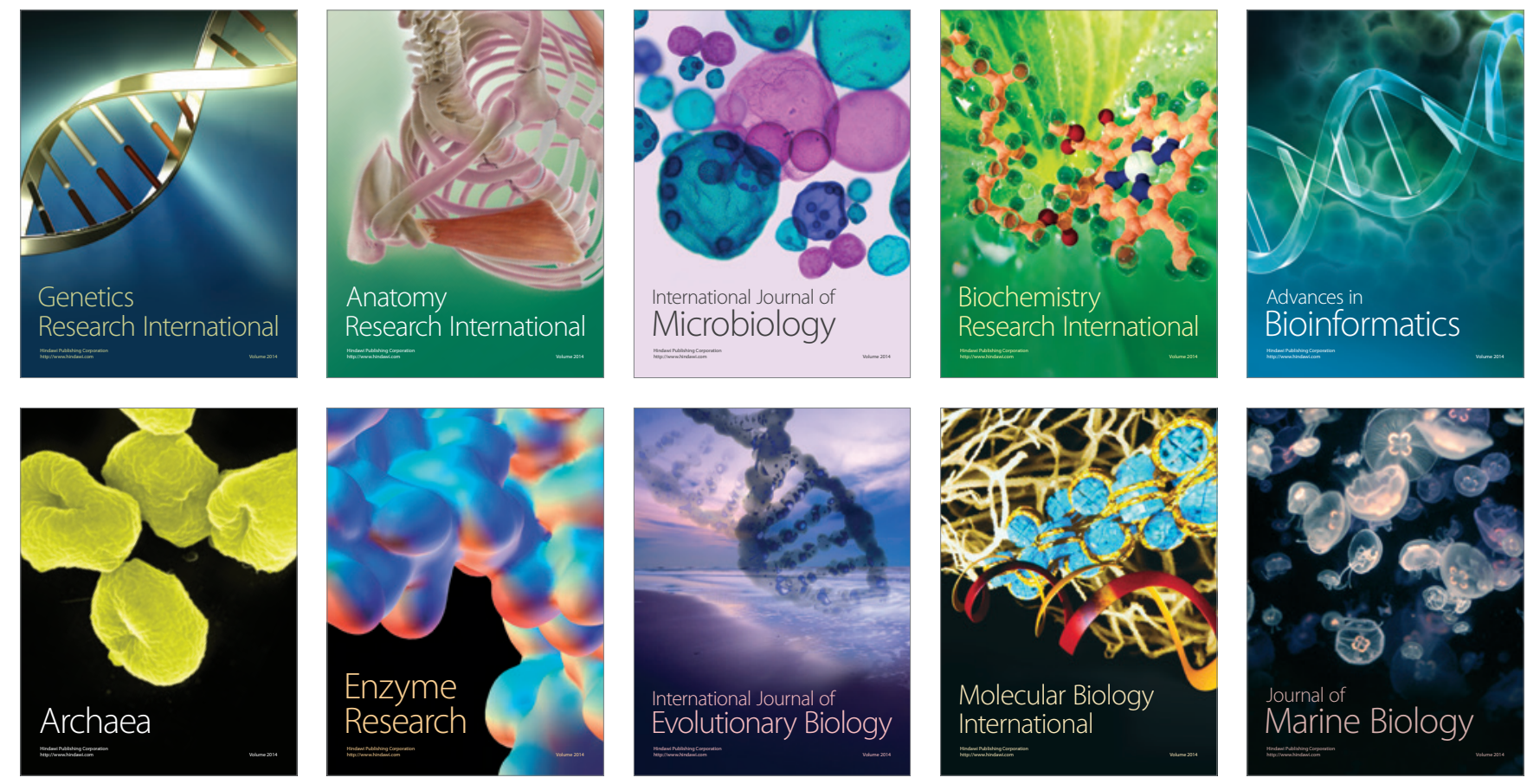